\title{
予後と在宅移行の面からみた腹膜播種陽性胃癌に対する 集学的治療の意義に関する検討
}

\author{
金沢医科大学一般 - 消化器外科 \\ 小坂 健夫菅谷 純一 吉田茂 \\ 中野 泰治 高島 茂樹
}

\begin{abstract}
胃癌の腹膜播種 (以下, P) に対する集学的治療について予後および在宅治療への移行の面から検討 した. 対象は1984年から1995年までに教室で手術した P 陽性胃癌108例である.一般化 Wilcoxon 検定 による予後の検討では, 胃切除, 術後化学療法 (以下, POC), 術前 performance status (以下, PS), 年齢, 術中化学療法 (以下, OC), N, P 程度が有意差を示した. Cox 比例 hazard model による多変 量解析では，胃切除，POC，P程度，OC，および性が有意な予後因子であったまた，在宅治療期間 は POC の併用化学療法群で長く, 在宅治療への移行率では, 年齢, PS, 併存基礎疾患, 術前化学療法, $\mathrm{N}$, 胃切除, および OC が有意差を認めた. 以上の結果から, P 陽性胃癌に対しては年柃および術前 PS を考慮した積極的な原発巣切除と化学温熱腹膜灌流法などの OC および術前後の併用化学療法が有用 であることが示唆された.
\end{abstract}

Key words : gastric cancer, surgery, chemotherapy, peritoneal metastasis, outpatient therapy

\section{はじめに}

胃癌の腹膜播種転移は，開腹時に約 $20 \% に$ 見られ， また, 胃癌治癒切除後の再発形式として最も頻度が高 く,しかもその治療は極めて困難である．私共の教室 ではこのような胃癌の腹膜転移に対し胃切除と化学療 法の併用を中心とした術中術後の集学的治療を積極的 に行ってきた。 ところで, 肝転移やリンパ節転移は CT やUS など画像診断を駆使することによって治療効果 の評価が可能なことが多いが, 腹膜播種転移では腫瘤 を形成する場合以外は，せいぜい腹水量や下部消化管 造影による間接的な形態学的変化, さらには進行した 腹膜播種患者でみられる腸閉塞症状の改善などで治療 効果を推測している。 そこで教室で施行してきた集学 的治療の成績について, その治療効果, 患者の予後の みならず患者がどれだけ長く在宅治療が可能であった かについて検討した。

\section{I. 対象と方法}

1984年 7 月から1995年 4 月までに，金沢医科大学一 般消化器外科で手術を施行し, 組織学的に確診の得ら れた腹膜播種陽性胃癌108例を対象に retrospective

$<1997$ 年 2 月12日受理>別刷請求先：小坂 健夫 于920-02 石川県河北郡内灘町大学 $1-1$ 金沢医科 大学一般・消化器外科
に検討した。臨床病理学的検討は胃癌取扱い規約 ${ }^{1)}$ 基づいて行った。平均年齢は62歳で, 男女比は $60 ： 48$ であった。これらの患者の治療開始前の performance status (以下, PS) は 0 が58例， 1 が35例， 2 が 5 例, 3 が 7 例, 4 が 3 例であった. 腹膜播種の程度は $\mathrm{P} 1$ が 26例, P2が34例, P3が48例で, 肝転移を24例に, 4 群 リンパ節転移を 37 例に, 他藏器浸潤を 49 例に認めた。 胃切除例は76例に施行し, それらの組織型は intestinal type が23例, diffuse type が53例であった (Table 1)。また治療開始前の何らかの併存疾患を有する症例 が59例に見られ, うち 2 つ併存疾患を有する症例が 17例，3つ以上が 8 例みられた。 それら併存疾患の内 訳は貧血などの血液疾患と心蔵疾患がそれぞれ 21 例, 呼吸器疾患が13例, 糖尿病と腎疾患がそれぞれ 8 例な どであった. 手術前治療（以下，PreOC）は13例に行 われ，その内容は5-fluorouracil (以下，5-FU) 系薬剤 を中心とし, cisplatin, mitomycin C(以下, MMC), methotrexate (以下, MTX) などの併用であった. 術 中化学療法 (以下, OC) は78例に行い，67例では手術 終了時に cisplatin $50 \sim 100 \mathrm{mg} /$ body あるいは MMC 20〜30mg/body を腹腔内に単回投与（以下, IP) し, 11例では化学温熱腹膜灌流治療 (chemo-hyperthermic peritoneal perfusion, 以下, CHPP)を行った. CHPP 
Table 1 Clinicopathologic features of 108 gastric cancers

\begin{tabular}{l|c}
\hline \multicolumn{1}{c|}{ Variables } & Values \\
\hline Age at operation(yr) & \\
Range & $32-87$ \\
Median & 65 \\
Gender & \\
Male & 60 \\
Female & 48 \\
Degree of paritoneal metastasis & \\
P1 & 26 \\
P2 & 34 \\
P3 & 48 \\
Performance status & \\
PS0 & 58 \\
PS1 & 35 \\
PS2 & 5 \\
PS3 & 7 \\
PS4 & 3 \\
Accompanied disease & \\
0 & 49 \\
1 & 34 \\
2 & 17 \\
$3 \leqq$ & 8 \\
\hline
\end{tabular}

\begin{tabular}{l|c}
\hline \multicolumn{1}{c|}{ Variables } & Values \\
\hline Hepatic metastasis & \\
$\mathrm{H}-$ & 84 \\
$\mathrm{H}+$ & 24 \\
Depth of invasion & \\
T2 & 3 \\
T3 & 55 \\
T4 & 49 \\
Lymph node status & \\
N1 & 11 \\
N2 & 29 \\
N3 & 18 \\
N4 & 37 \\
Histologic grade & \\
Intestinal & 23 \\
Diffuse & 53 \\
\hline
\end{tabular}

の方法は, peritoneal cavity expander を用いて腹腔 を拡張させ, 液温は $40 \sim 42^{\circ} \mathrm{C}$, cisplatin $300 \mathrm{mg}$ と MMC $30 \mathrm{mg}$ を温生食12L に溶解した灌流液を用い, 15 分ずつ 3 回に分割し 45 分間施行した。術後化療（以 下, POC) は74例に行い，その内訳は，5-FU 系薬剤単 独 (以下, FU) が20例, $\mathrm{MMC}+5-\mathrm{FU}$ (以下， MF) が19例, cisplatin+5-FU(以下, FP) が20例, MTX+ 5-FU(以下, FMTX) が15例であった. MMC, cisplatin およびMTX はいずれも少量投与法を，1～2 週に 1 回の割で投与した．薬剤の投与経路は全身投与を 52 例 に動脈内投与を 22 例に行った. 動脈内投与の方法は力 テーテルの先端を Th9～10に留置し，左鎖骨下の前胸 壁皮下に埋没したBlood access device を用い注入し た。術後免疫療法は46例に行い, その内訳では Picibanil を25例に, Lentinan を21例に, Krestin を14 例に投与した。推計学的検討は，2 群の平均値の差に は Student の $\mathrm{t}$ 検定を, 百分率には $\chi^{2}$ 検定を用いた。 さらに, 予後については化学療法開始日あるいは手術 日からの生存日数であらわし, 生存率は KaplanMeier 法2)で算出した，2 群の生存曲線間の比較は一 般化Wilcoxon 検定で行った。予後におよ济す各因子 の重みについての多変量解析は Cox proportional hazard model ${ }^{3)}$ 用い検討した。いずれも危険率 $5 \%$

未満の場合を有意とした。

\section{II. 結 果}

（1）手術死亡率と合併症発生率

手術後 30 日以内の手術直接死亡は, 胃切除例で 3 例 $(3.9 \%)$, 非切除例で 8 例 $(25.0 \%)$, 全体で11例 (10.1\%)にみられ，切除例に比べ非切除例で有意に高 率であった $(\mathrm{p}<0.001)$ 。一方, 手術後の合併症は胃切 除例で15例 (19.7\%), 非切除例で 6 例 (18.8\%), 全 体として21例 (19.4\%) で，胃切除の有無では差が見 られなかった。 その内訳では，胃切除に関連した合併 症は縫合不全 5 例と腹腔内膿瘍 2 例で, 切除に関連し ないものでは急性腎不全 5 例, 肝不全 3 例, 呼吸不全 3 例, 消化管出血 - 術前化療後の骨髄抑制・初回手術 時大腸穿孔に引き続く敗血症おのおの 1 例など, 胃癌 の進行によりもたらされた病態が手術を契機に増悪し たものであった。

（2）臨床病理学的因子と予後

対象症例全体の予後は，生存期間中央值 (median survival time：以下, MST) が133日， 1 年・2 年・ 3 年・5 年の各生存率がそれぞれ $19.4 \%, 8.3 \%, 5.9 \%$, $3.6 \%$ であり, 3 年以上生存は 5 例, 5 年以上生存は 3 例にみられた. 播種程度からみた MST はP1が210日, P2が215日，P3が101日，また 1 年生存率 (以下， 1 生 
率) はそれぞれ $38 \% ， 15 \% ， 11 \%$ をし，P症例は P2 症例に比べ有意に $(\mathrm{p}=0.02)$ 予後不良で, また，P1症 例との対比では予後不良な傾向 $(\mathrm{p}=0.06)$ を認めた (Fig. 1).その他の臨床病理学的因子別の検討では, 前

Fig. 1 Overall cumulative survival rates for patients with gastric cancer according to degree of peritoneal metastasis. P1, P2 and P3, see the text. ${ }^{*}, \mathrm{p}<0.05$ vs $\mathrm{P} 2$ and $\mathrm{p}<0.1$ vs $\mathrm{P} 1$.

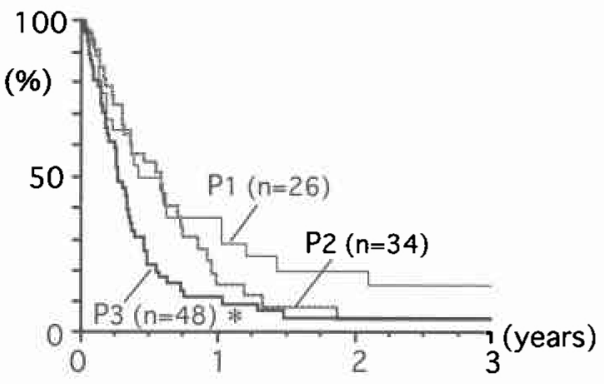

PS の良好例・リンパ節転移程度の低い例・年齢が70歳 以下の症例の予後が良好であった（Table 2).

（3）胃切除と予後

胃切除を行った症例では MST が203日，1生率が 27.6\%を示したのに対し, 非切除例では MST が76日, 1 生率が $0 \%$ で胃切除例で有意に良好な予後を示した $(\mathrm{p}=0.00001)$ (Fig. 2).

（4）術前化学療法 (PreOC) と予後

PreOC の有無別の背景因子を検討すると, 年齢が71 歳以上の症例で施行例が少ない傾向 $(p=0.08)$ であっ たが， $\mathrm{P}$ 程度・前 $\mathrm{PS} \cdot \mathrm{T} \cdot \mathrm{N} ・$ 切除の有無別には差が なかった.PreOCの有無からみた予後の比較では, PreOCを行った患者のMST が225日， 1 生率は $33.6 \%$ に対し，行わなかった患者の MST が133日，1 生率は $17.4 \%$ で前者では後者に比較してやや良好な予 後を示したが有意差はなかった（ $\mathrm{p}=0.17 ）$ (Fig. 3). 胃切除の有無からみた, PreOC 別の予後の比較でも差

Table 2 Prognostic factors entered into univariate analysis to determine their effect on overall survival rate

\begin{tabular}{|c|c|c|c|c|}
\hline Factors & Categories & MST (days) & $1 \mathrm{YS}(\%)$ & $\mathrm{p}$-value \\
\hline Gastric resection & $(-)$ vs $(+)$ & 76 vs 203 & 0 vs 26 & 0.00002 \\
\hline $\begin{array}{l}\text { Postoperative } \\
\text { chemotherapy }\end{array}$ & $\begin{array}{l}(-) \text { vs tegafur } \\
(-) \text { vs combined } \\
\text { tegafur vs combined }\end{array}$ & $\begin{array}{r}54 \text { vs } 224 \\
54 \text { vs } 197 \\
224 \text { vs } 197\end{array}$ & $\begin{array}{r}7 \text { vs } 13 \\
7 \text { vs } 28 \\
13 \text { vs } 28\end{array}$ & $\begin{array}{l}0.00005 \\
0.00001 \\
0.78\end{array}$ \\
\hline PS & 0,1 vs $2,3,4$ & 155 vs 48 & 23 vs 0 & 0.0002 \\
\hline $\begin{array}{l}\text { Operative } \\
\text { chemotherapy }\end{array}$ & $\begin{array}{l}\mathrm{IP}(-) \text { vs } \mathrm{IP}(+) \\
\mathrm{IP}(-) \text { vs } \mathrm{CHPP} \\
\mathrm{IP}(+) \text { vs } \mathrm{CHPP}\end{array}$ & $\begin{array}{l}134 \text { vs } 125 \\
134 \text { vs } 225 \\
125 \text { vs } 225\end{array}$ & $\begin{array}{l}15 \text { vs } 18 \\
15 \text { vs } 41 \\
18 \text { vs } 41\end{array}$ & $\begin{array}{l}0.9 \\
0.007 \\
0.007\end{array}$ \\
\hline Depth of invasion & $\mathrm{T} 2,3$ vs $\mathrm{T} 4$ & 171 vs 114 & 25 vs 13 & 0.06 \\
\hline $\begin{array}{l}\text { Degree of } \\
\text { peritoneal } \\
\text { metastasis }\end{array}$ & $\begin{array}{l}\mathrm{P} 1 \text { vs } \mathrm{P} 2 \\
\mathrm{P} 1 \text { vs } \mathrm{P} 3 \\
\mathrm{P} 2 \text { vs } \mathrm{P} 3\end{array}$ & $\begin{array}{l}210 \text { vs } 215 \\
210 \text { vs } 101 \\
215 \text { vs } 101\end{array}$ & $\begin{array}{l}38 \text { vs } 15 \\
38 \text { vs } 11 \\
15 \text { vs } 11\end{array}$ & $\begin{array}{l}0.9 \\
0.06 \\
0.02\end{array}$ \\
\hline Gender & $m$ vs $f$ & 127 vs 181 & 14 vs 26 & 0.26 \\
\hline Lymph node status & $\mathrm{NO}, 1,2$ vs $\mathrm{N} 3,4$ & 203 vs 114 & 37 vs 9 & 0.006 \\
\hline Hepatic metastasis & $(-)$ vs $(+)$ & 146 vs 114 & 21 vs 13 & 0.19 \\
\hline Age & -70 vs $71-$ & 197 vs 94 & 26 vs 8 & 0.001 \\
\hline Immunotherapy & $(-)$ vs $(+)$ & 210 vs 171 & 19 vs 27 & 0.72 \\
\hline Combined disease & 0.1 vs 2 or more & 141 vs 133 & 22 vs 15 & 0.28 \\
\hline PreOC & $(-)$ vs $(+)$ & 133 vs 225 & 17 vs 34 & 0.17 \\
\hline Route & systemic vs aortic & 181 vs 218 & 19 vs 36 & 0.65 \\
\hline
\end{tabular}

POC, postoperative chemotherapy ; PS, performance status ; OC, operative chemotherapy ; PreOC ; preoperative chemotherapy ; IP, intraperitoneal chemotherapy ; CHPP, chemo-hyperthermic peritoneal perfusion; MST, median survival time; 1 YS, 1 year survival 
はみられなかった。

（5）術中化学療法 $(O C)$ と予後

$\mathrm{OC}$ の有無別の背景因子を検討すると, $\mathrm{P}$ 程度・年 蔽・前 PS・T・N・切除の有無別には差がなかった。

Fig. 2 Overall cumulative survival rates for patients undergoing gastric resection compared with no resection. $R$, resection; NR, no resection. *, $\mathrm{p}<0.01$ vs NR.

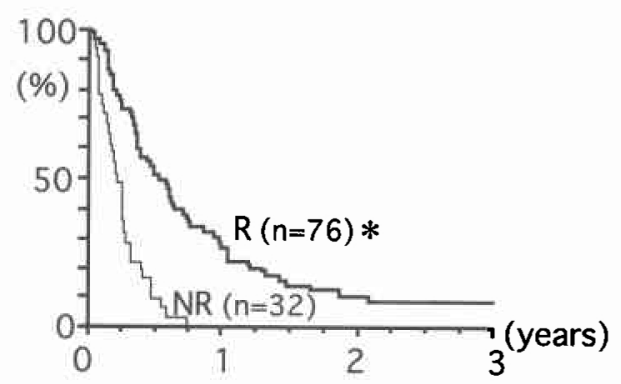

Fig. 3 Overall cumulative survival rates for patients undergoing preoperative chemotherapy (PreOC) compared with no PreOC. Statistically not significant $(p=0.17)$.

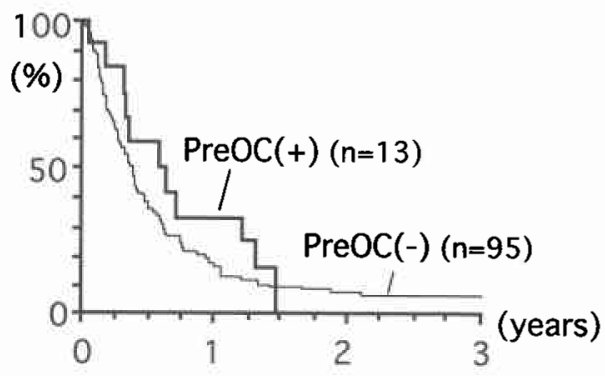

$\mathrm{OC}$ の内容别に MST と 1 生率について検討すると, OC 非施行例ではおのおの134日と $14.5 \%$, IP 施行例て は125日と18.2\%であり，CHPP施行例では225日と $40.9 \%$ と前 2 者に比べ有意に予後良好であった（ $\mathrm{p}=$ 0.007)。また胃切除の有無別に検討しても同様に CHPPの予後が良好な傾向を示した（Fig.4).

(6) 術後化学療法 (POC) と予後

POC 非施行例の背景因子を検討すると高齢者 $(\mathrm{p}=$ $0.0008)$, 前 PS 不良例 $(p=0.04)$ が有意に多かった。 $\mathrm{P}$ 程度別には P1の 6例（23\%)，P2の11例（32\%）お よび P3の16例（34\%）にPOCが行えなかった.POC の内容別には背景因子に差がなかった。しかし， Tegafur 単独例と併用化学療法施行群の生存曲線間 には有意差はないものの，3 年以上生存例は後者にの み認められた（Fig. 5)。併用化学療法の内容別には FMTX 療法が, 特に切除例において MST および 1 生 率ともに良好であるものの有意差は見られなかった (Fig. 6).いずれも症例数が10例前後であり，今後症例 の増加とともに有意となることが考えられる，化学療 法の投与経路別には，1生率が全身投与で19\%であっ たのに対し動脈内投与では $36 \%$ と高率を示したが有意 差はなく, 胃切除の有無別にみても差は認めなかった (Fig. 7).

（7）免疫療法と予後

POCを行った症例に限って免疫療法の有無別に予 後を検討したが有意な差は見られなかった。

（8）単変量解析の結果

以上の一般化 Wilcoxon 検定による単変量解析で有 意差を示した因子は, 胃切除 $(p=0.00001), P O C$ 非施 行 $(\mathrm{p}=0.00001$ vs 併用化学療法, $\mathrm{p}=0.00007$ vs

Fig. 4 Survival rates for patients with gastric cancer with peritoneal metastasis subdivided by procedures of operative chemotherapy. (a), overall ; (b), no gastric resection ; (c) gastric resection. IP, intraperitoneal chemotherapy; CHPP, chemo-hyperthermic peritoneal perfusion. $\star, \mathrm{p}<0.01$ vs IP $(-)$ and IP $(+) ; \#, \mathrm{p}<0.1$ vs IP $(+) ;{ }^{*}, \mathrm{p}<0.05$ vs IP $(-)$ and $\mathrm{p}<0.1$ vs IP $(+)$.
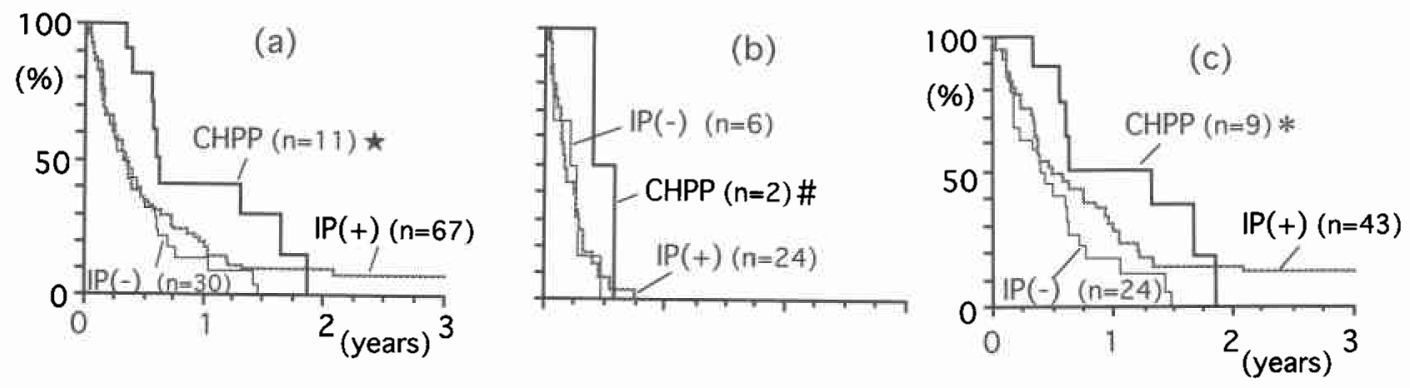
tegafur 単独), 前 $P S(p=0.0002)$, 年歯 $(p=0.001)$, IOC $の$ CHPP $(p=0.007$ vs IP $(-), p=0.007$ vs IP $(+)), N(p=0.006)$, 播種程度 P3 ( $\mathrm{p}=0.02$ vs P2) の順であった（Tabl 2).

（9）多変量解析の結果

多変量解析で有意の重みを示す予後因子と判定でき たものは, 胃切除 $(\mathrm{p}=0.00002), \operatorname{POC}(\mathrm{p}=0.00008)$,

Fig. 5 Overall cumulative survival rates for patients with gastric cancer with peritoneal metastasis subdevided by procedures of postoper. ative chemotherapy (POC).

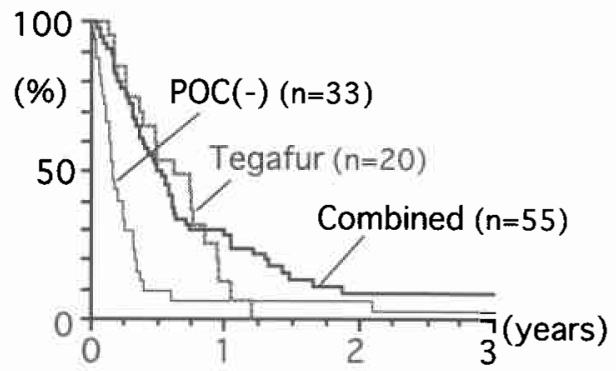

P程度 $(\mathrm{p}=0.032), \mathrm{OC}(\mathrm{p}=0.032)$ ，および性（ $\mathrm{p}=$ 0.049）であった（Table 3).

（10）在宅治療への移行

POC 別の)初回入院期間は化学療法の内容別に差が なかった。また, 総在宅期間は併用化学療法施行例で $233 \pm 518$ 日と FU 単独の114 191 日より長い傾向であ り，これを胃切除例に限り検討しても同様の結果で あった. 生存期間にしめる在宅率では化学療法の内容 別に差がなかった (Table 4). 在宅治療への移行率を 検討すると，有意差を示した因子は，年齢 (70以下 vs 71以上, $\mathrm{p}=0.00001)$, PS $(0-1$ vs $2-4, \mathrm{p}=0.0002)$, 併存疾患 (0-1 vs 2 以上, $\mathrm{p}=0.03), \operatorname{PreOC}(-\mathrm{vs}+$, $\mathrm{p}=0.046), \mathrm{N}(2$ 以下 vs 3 以上, $p=0.04)$, 胃切除 $(-$ vs,$+ p=0.002)$, OC (- vs CHPP, $p=0.002$ かつ IP vs CHPP, $\mathrm{p}=0.01)$ であった。

\section{III. 考 察}

胃切除例が非切除例に比較して有意に予後良好で あったのは当然であるが, 胃癌の進展度を含めた複数 の説明因子による多変量解析の結果でも胃切除は最も 強い重みを示す予後因子であった．野波ら゙は763例の

Fig. 6 Survival rates for patients with gastric cancer with peritoneal metastasis undergoing combined chemotharapy subdivided by procedures of postoperative chemotherapy. (a), overall; (b), no gastric resection; (c) gastric resection. FM, tegafur + mitomycin C; FP, tegafur + cisplatin ; FMTX, tegafur + methotrexate. Statistically not significant.
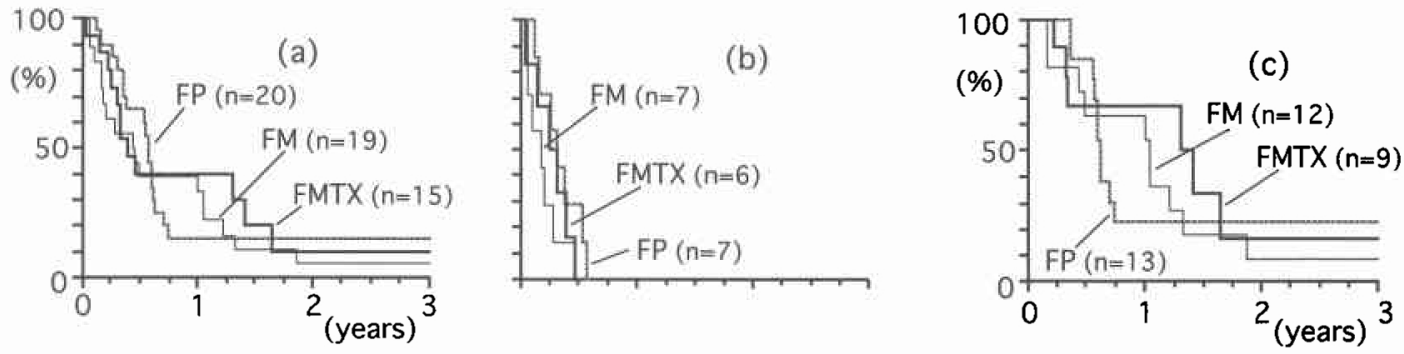

Fig. 7 Survival rates for patients undergoing postoperative chemotherapy for gastric cancer with peritoneal metastasis subdivided by routes of administration. (a), overall ; (b), no gastric resection; (c) gastric resection. Statistically not significant.
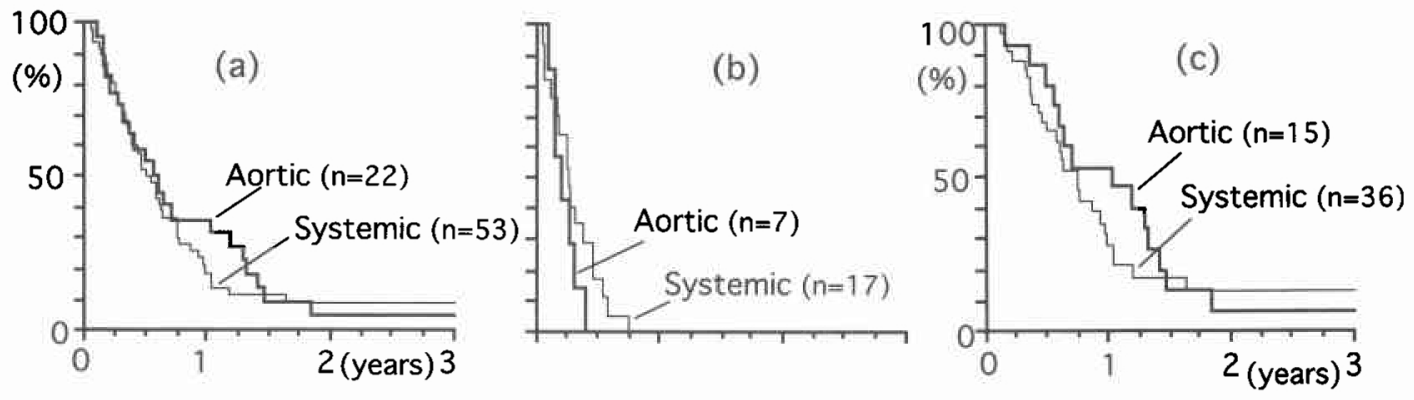
Table 3 Prognostic factors entered into multivariate analysis to determine their effect on overall survival rate

\begin{tabular}{l|l|l}
\hline \multicolumn{1}{c|}{ Factors } & \multicolumn{1}{|c}{ Categories } & p-value \\
\hline Gastric resection & $(-) /(+)$ & 0.00002 \\
POC & $(-) /$ tegafur/combined & 0.00008 \\
$\mathrm{P}$ & $1 / 2 / 3$ & 0.032 \\
OC & $\mathrm{IP}(-) / \mathrm{IP}(+) / \mathrm{CHPP}$ & 0.033 \\
Gender & $\mathrm{m} / \mathrm{f}$ & 0.049 \\
Age & $-70 / 71-$ & 0.15 \\
$\mathrm{PS}$ & $0,1 / 2,3,4$ & 0.15 \\
Nodal status & $\mathrm{NO}, 1,2 / \mathrm{N} 3,4$ & 0.42 \\
Depth of invasion & $\mathrm{T} 2,3 / \mathrm{T} 4$ & 0.51 \\
Immunotherapy & $(-) /(+)$ & 0.51 \\
Route & $\mathrm{systemic/aortic}$ & 0.64 \\
Combined disease & $0,1 / 2$ or more & 0.75 \\
PreOC & $(-) /(+)$ & 0.95 \\
Hepatic metastasis & $(-) /(+)$ & 0.95 \\
\hline
\end{tabular}

$\mathrm{POC}$, postoperative chemotherapy; $\mathrm{P}$, degree of peritoneal metastasis; OC, operative chemotherapy; PS, performance status ; PreOC, preoperative chemotherapy ; IP, intraperitoneal chemotherapy; CHPP, chemohyperthermic peritoneal perfusion
腹膜播種胃癌の検討結果から, 播種程度より手術の根 治度および胃切除の有無がより強く予後に影響をおよ ぼすことを示し, 可及的な減量手術と補助化学療法の 有用性を述べた。貝原ら゙は腹膜播種胃癌での長期生 存例が漿膜浸潤面積が狭く，リンパ節転移が少なく， かつリンパ節郭清が行われている症例であったことか ら，P1・P2であれば胃癌の切除および可及的なリンパ 節郭清を行うべきであると報告した。加藤ら ${ }^{6}$ は Cox 比例 hazard model 分析を用いた腹膜播種胃癌197例 の多変量解析による検討から, 予後因子としての重み はリンパ節転移 $(\mathrm{p}=0.0000)$ ・播種程度 $(\mathrm{p}=0.09)$ ・ 切除 $(p=0.007) \cdot$ 肉眼型 $(p=0.03)$ ・リンパ節郭清 $(\mathrm{p}=0.09) \cdot$ 深達度 $(\mathrm{p}=0.14)$ の順であったとし，そ の結果から, 癌巣の完全な摘除およびリンパ節郭清が 腹膜播種胃癌の治療に有用と結論した。これらの報告 は, 本研究結果と一致するものであり, 腹膜播種胃癌 では,できる限り腫瘍を摘除することが予後改善につ ながることを示唆する。

OC については，IP は非施行例に比較して予後に差 を認めなかったが，CHPP 施行例では IP や非施行例

Table 4 First hospital and total home care duration, and home care duration rate according to postoperative multimodal therapy

\begin{tabular}{|c|c|c|c|}
\hline & $\begin{array}{l}\text { First hospital } \\
\text { duration(days) }\end{array}$ & $\begin{array}{l}\text { Total home care } \\
\text { duration(days) }\end{array}$ & $\begin{array}{l}\text { Home care duration } \\
\text { /total survival duration }\end{array}$ \\
\hline \multicolumn{4}{|l|}{ POC } \\
\hline \multicolumn{4}{|l|}{ All cases } \\
\hline $\operatorname{POC}(-)$ & $64 \pm 52$ & $72 \pm 318$ & $0.1 \pm 0.2$ \\
\hline $\mathrm{FU}$ & $47 \pm 19$ & $114 \pm 91$ & $0.4 \pm 0.3 \star$ \\
\hline Combined & $59 \pm 33 \S$ & $233 \pm 518 \S$ & $0.4 \pm 0.3 \star$ \\
\hline FM & $51 \pm 26$ & $258 \pm 541$ & $0.4 \pm 0.3 \star$ \\
\hline $\mathrm{FP}$ & $64 \pm 27$ & $274 \pm 709$ & $0.4 \pm 0.3 \star$ \\
\hline FMTX & $64 \pm 44$ & $157 \pm 239$ & $0.3 \pm 0.3 \star$ \\
\hline \multicolumn{4}{|c|}{ Gastrectomy (+) } \\
\hline $\operatorname{POC}(-)$ & $73 \pm 55$ & $91 \pm 357$ & $0.1 \pm 0.2$ \\
\hline FU & $47 \pm 12 \#$ & $124 \pm 84$ & $0.5 \pm 0.3 \star$ \\
\hline Combined & $54 \pm 24$ & $364 \pm 624 \%$ & $0.5 \pm 0.3 \star$ \\
\hline FM & $51 \pm 23$ & $369 \pm 629$ & $0.5 \pm 0.3 \star$ \\
\hline FP & $62 \pm 32$ & $453 \pm 921$ & $0.5 \pm 0.2 \star$ \\
\hline FMTX & $45 \pm 14 \star$ & $265 \pm 265$ & $0.6 \pm 0.2 \star$ \\
\hline \multicolumn{4}{|l|}{ Route* } \\
\hline Systemic & $55 \pm 30$ & $210 \pm 519$ & $0.4 \pm 0.3$ \\
\hline Aortic & $61 \pm 31$ & $186 \pm 219$ & $0.4 \pm 0.3$ \\
\hline \multicolumn{4}{|c|}{ Immunotherapy* } \\
\hline$(-)$ & $58 \pm 35$ & $227 \pm 502$ & $0.4 \pm 0.4$ \\
\hline$(+)$ & $56 \pm 28$ & $192 \pm 434$ & $0.4 \pm 0.3$ \\
\hline
\end{tabular}

POC, postoperative chemotherapy ; FU, 5 -fluorouracil derivaties ; FM, FU + mitomycin C ; FP, FU+ cisplatin ; FMTX, FU + methotrexate; *, POC (+); ※, p <0.05 vs FU ; §, p <0.1 vs FU; $\star$, p $<0.05$ vs $\mathrm{POC}(-) ; \#, \mathrm{p}<0.1$ vs $\mathrm{POC}(-)$ 
に比べ良好な予後を示した，腹膜播種に対する抗癌剤 の単回投与 (IP) については, 平塚ら”は MMC 40mg を生食 $1,000 \mathrm{ml}$ に溶解し60分間腹腔内に投与したとこ ろ, 播種陽性例での一年生存率は非施行例の $33 \%$ に比 較し投与例で $78 \%$ と有意に良好であったと述べてい る。狩野ら ${ }^{81}$ は胃癌腹膜播種93例を対象にCDDP 50〜 $70 \mathrm{mg} / \mathrm{m}^{2}$ を投与した例と，MMC あるいは $\mathrm{OK}$. 432投与例および無処置例との比較から CDPP 投与群 では MST が11月を示したのに対し他の群では $7 〜 8$ 月で CDDP 投与により良好な予後が得られたと報告 している．手術時に腹腔内に投与する薬剂の種類およ び剤型については近藤ら ${ }^{9}$ は徐放性の活性炭吸着 MMC をもちいた治療から，P1〜2では対照群に対し 延命効果が得られたが P3では得られなかったとして いる.腹腔内温熱化学療法は古賀ら ${ }^{(0)}$ および Fujimoto ら ${ }^{11)}$ の報告にはじまり，小林ら ${ }^{12}$ は MMCを併用した 温熱療法（IPHP）を腹膜播種例に行った結果，MST が対照の 4 か月に比べ18か月と有意に延長させること ができたと報告した。一方, 藤村ら ${ }^{13)}$ は墏膜浸潤陽性例 に対し cisplatinとMMCを併用した温熱治療 (CHPP)を行ったところ, P0〜P1では施行例で有意に 予後良好であったが, P2〜P3では差がなかったと述べ ている。CHPP が漿膜浸潤胃癌の再発予防に有用で あったとする報告は多いもの ${ }^{13114)}$ の，すでに播種が存 在する症例では, 有効であるとするもの ${ }^{12)}$, 差がない とする報告 ${ }^{13)}$ が見られ意見の一致はいまだ得られてい ない. 腹腔内に抗腫瘍哓を投与するにあたっては腹腔 からの吸収経路を考虑しなければならない。その経路 は主に 2 つるとされ，分子量の小さい薬物の大部分 （30１00\%）は臟側腹膜から毛細血管に入り門脈を経 て肝に至る経路で吸収され，一部は壁側腹膜から吸収 されるといわれ，また分子量の大きい薬物やコロイド 状のもの，あるいは腫崵細胞などは主としてリンパ路

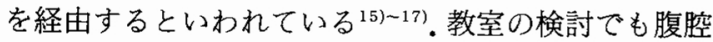
内投与された cisplatin や MMC は血中においても比 較的有効な AUC が得られており，腹腔内投与のみで も有効な結果が得られる理由の 1 つと考えられる ${ }^{18)}$. また実験的および臨床的に腫湟表面からの薬剤浸透は $2 \mathrm{~mm}$ 程度といわれることからも,腹腔内投与による直 接効果は微小な病変に限られるといえる17199.

POC の内訳別には 3 年以上生存例は併用化学療法 施行群にのみ認められた。併用化学療法の内容別には FMTX 療法が,特に切除例において MST および 1 年 生存率ともに良好であった. POC を行った症例に限っ
て免疫療法の有無別に予後を検討したが有意な差は見 られなかった。一方，化学療法の投与経路別には，1 年生存率が全身投与で $19 \%$ あ゙あのに対し動脈内投与 で36\%と高いものの有意差はなく，胃切除の有無別に も差は認めなかった。待木ら ${ }^{201}$ は 6 例の $\mathrm{P} 3$ 症例に5FU, MMC あるいは ADR を用いた帚選択的動注化学 療法を行ったところ，奏効例はなかったが非動注例と 比較して予後良好であったと報告した．腹膜播種胃癌 に対する覀選択的動注療法は，肝転移に対する選択的 動注療法などと比べ腫瘍内の薬剤濃度や副作用の面で 課題が残されているものと思われる。

太田 ${ }^{21}$ は手術不能の進行成人癌に対する化学療法の 効果別ランクを A, B, C, D の 4 種に分け, 胃癌をや や有効のランク C に分類し，このような抗癌剤に抵抗 性の癌の場合は緩和的化学療法が実施されるべきと述 べた。漆崎 ${ }^{221}$ によればその具体的な内容とは, 抗癌剤の 副作用の出現の抑制, 生存期間の延長, 症状の改善, およびQOLの維持を目的とすることとされる。そう いう観点から各因子別に総在宅期間を検討したが, POC で併用化学療法が FU 単独より長い傾向であっ た. 在宅治療への移行率では有意差を認めた臨床病理 学的因子は年齢 (70以下), PS ( 0 あるいは 1$)$, 併用

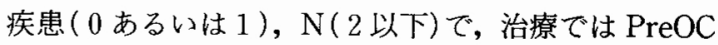
(+), 胃切除 (+), CHPP (+) であった。

以上の結果から,腹膜播種陽性胃癌に対しては年齢, 術前PS および併存疾患を考慮した積極的な原発巣切 除と CHPP などの OC および術前後の併用化学療法 が生存期間および在宅期間の面から有用であることが 示唆された。

\section{文献}

1）胃癌研究会編，胃癌取扱い規約. 改訂第12版。金原 出版, 東京, 1993, p1-89

2) Kaplan EL, Meier P: Nonparametric estimation from incomplete observations. J Am Statistical Assoc 53:457-481, 1958

3) Cox DR: Regression models and life-tables. J R Statistical Soc Ser B 34：187-220，1972

4）野波敏明, 中島聰總,高木国夫ほか：胃癌腹膜播種 症例の治療. 日消外会誌 $14: 1571-1575,1981$

5）貝原信明, 岡本恒之, 前田迪郎ほか：腹膜播種を伴 う胃癌の手術。消外 7:1525-1528, 1984

6）加藤道男, 河村史朗, 森下 透ほか：胃癌の術後遠 隔成績に及ぼす因子の検討一Cox の比例ハザード モデルによる OK-432腹膜内投与の評価. 日消外会 誌 23：2741-2746，1990

7) 平塚正弘, 古河 洋, 岩永 剛活か：動注癌化学療 
法.七ト胃癌の平均的 IC50を満足する Mitomycin $\mathrm{C}$ 腹腔内投与量法の薬理動態と遠隔成績. 癌と化 療 $17: 1541-1545,1990$

8）狩野タダシ,川見弘之, 神殿 哲任か：胃癌の腹膜 播種例に対する Cisplatin 術中腹腔内投与。癌と化 療 $17: 233-237,1990$

9）近藤慎治, 沢井清司, 山口俊晴ほか：腹膜播種再発 防止を目的とした活性炭吸着マイトマイシンC 術 中腹腔内投与について. 日消外会誌 $22: 989-$ 992, 1989

10）古賀成昌, 浜副隆一, 前田迪郎：胃癌腹膜転移予防 のための持続温熱腹膜灌流療法の試み. 外科治療 $52: 308-311,1985$

11) Fujimoto S, Shrestha RD, Kokubun M, et al: Intraperitoneal hyperthermic perfusion combined with surgery effective for gastric cancer patients with peritoneal seeding. Ann Surg 208:36-41, 1988

12）小林国力, 藤本 茂, セレスタ RD ほか：動注癌化 学療法. 生存率からみた進行胃癌症例に対する腹 腔内温熱化学療法の臨床効果. 癌と化療 17 : 1617-1621, 1990

13）藤村 隆, 米村 豊, 浦出雅昭ほか：胃癌の腹膜播 種に対する cisplatin, mitomycin C 併用持続温熱 腹膜灌流。日癌治療会誌 24：1415-1424，1989

14) Kaibara $N$, Hamazoe $R$, Iisuka $Y$ et al:
Hyperthermic peritoneal perfusion combined with anticancer chemotherapy as prophylactic treatment of peritoneal recurrence of gastric cancer. Hepatogastroenterology $36: 75-78$, 1989

15) Tayler I: Adjuvant liver perfusion in colorectal cancer. Br Med J 2:1320-1322, 1977

16) Meyers CE: Pharmacology of intraperitoneal chemotherapy. Cancer Invest 1:395-407, 1983

17) 平林光司：がんの局所化学療法. 腹腔内投与. 癌と 化療 $16: 180-186,1989$

18）小坂健夫, 菅谷純一, 瀬島照弘ほ力：胃癌腹膜播種 に対士る集学的治療の検討. 日外科系連会誌 20:127-131, 1995

19）米村 豊, 藤村 隆, 竹川 茂ほか：腹膜播種を有 する Borrmann 型胃癌に対する温熱・化学療法と second look operation. 日消外会誌 22 : 907912, 1989

20）待木雄一, 二村雄二, 井垣 啓ほか：根治手術不能 胃癌の治療一特に姑息的切除と亜選択的動注化学 療法の有用性について一, 日癌治療会誌 26 ： 2195-2202, 1991

21）太田和雄：QOL からみた癌化学療法の諸問題. 嵒 治療と QOL $1: 3-5,1992$

22）漆崎一朗：QOLからみた癌化学療法の在り方. Oncologia 27:262-267, 1994

\title{
Retrospective Studies on Multiple Modalities of Therapy for Advanced Gastric Cancer with Peritoneal Metastasis from the Aspect of Patient Prognosis and Outpatient Interval
}

\author{
Takeo Kosaka, Jun-ichi Sugaya, Shigeru Yoshida, \\ Yasuharu Nakano and Shigeki Takashima \\ Department of Surgery II, Kanazawa Medical University
}

We investigated whether multiple modalities of therapy for advanced gastric cancer with peritoneal metastasis could lengthen the patient's survival time and outpatient interval. Between 1984 and 1995, 108 patients undergoing surgery for gastric cancer at our department were found to have peritoneal metastasis. With generalized Wilcoxon test, gastrectomy, postoperative chemotherapy (POC), performance status (PS), age, operative peritoneal chemotherapy $(\mathrm{OC})$, nodal status $(\mathrm{N})$ and peritoneal status $(\mathrm{P})$ showed significant differences. Multivariate analysis with Cox's proportional hazard model showed gastrectomy, POC, P, OC and sex are significantly potent prognostic factors. In the aspect of home care duration, age, PS, complications, preoperative chemotherapy, N, gastrectomy and OC showed significant differences. These results suggests that gastrectomy and chemotherapy in the perioperative period might be useful for gastric cancer with peritoneal metastasis.

Reprint requests: Takeo Kosaka Department of Surgery II, Kanazawa Medical University 1-1 Daigaku, Uchinada, Kahokugun, 920-02 JAPAN 